\title{
Ginkgo biloba extract (EGb761) did not express estrogenic activity in an immature rat uterotrophic assay
}

\author{
Byeonghak Moon ${ }^{1 *}$, Wonchan Kim ${ }^{1,2 *}$, Cho Hee Park', Seung Min $\mathrm{Oh}^{1}$ \\ 'Department of Nanofusion Technology, Hoseo University, Asan, Republic of Korea; ${ }^{2}$ AB solution, Suwon, Republic of Korea
}

Ginkgo biloba is a dioecious tree that has been used in traditional Chinese medicine for about 5,000 years. In previous studies on ginkgo biloba extract (EGb761) using in vitro systems, we confirmed that EGb761 has biphasic effects on estrogenicity. In this study, we evaluated the agonistic and antagonistic activities of EGb761 using a uterotrophic assay in immature female rats. To evaluate agonistic and antagonistic effects of EGb761 on uterus, 21-day-old immature Sprague-Dawley (SD) female rats were treated with EGb761 (100, 200, or $400 \mathrm{mg} / \mathrm{kg}$ ) by oral gavage, $10 \mu \mathrm{g} / \mathrm{kg}$ of estradiol (E2) or $1 \mathrm{mg} / \mathrm{kg}$ tamoxifen (TM) by subcutaneous injection, or with EGb761 plus E2 or TM for 3 consecutive days. At the end of the treatment period, animals were sacrificed and their body weights and organ weights (liver, lung, spleen and kidney) were measured. In addition, estrogen-related gene expressions (IGFBP-1 in liver and CaBP-9 in uterus) were determined. During the experiment, no animal showed clinical signs, a change in body weight or died. EGb761 treatment alone had no effect on absolute/relative uterine weight, luminal epithelial cell height (LECH, $\mu \mathrm{m})$, or luminal circumference $(\mathrm{LC}, \mu \mathrm{m})$. In addition, uterine weights, LECHs, and LC induced by E2 or TM were not significantly changed by EGb761 at any dose. These results collectively suggested EGb761 has no agonistic/antagonistic effects in utero.

Keywords: Ginkgo biloba extract, EGb761, uterus, uterotrophic assay

\section{INTRODUCTION}

Ginkgo biloba is a dioecious tree that has been used in traditional Chinese medicine for about 5,000 years and is now also commercially cultivated in France and the USA [1]. Clinically, extracts of Ginkgo biloba extract (GBE) of leaves have been used to treat cerebrovascular and peripheral vascular insufficiency [2] and CNS disorders such as Alzheimer's disease and cognitive deficits [3]. The standardized extracts of Ginkgo biloba leaves, EGb761 (trade names Tebonin ${ }^{\circledR}$, Tanakan ${ }^{\oplus}$, Rökan ${ }^{\circledR}$ ), were introduced by the Dr. Willmar Schwabe group (Karlsruhe, Germany) and was developed in Europe [4]. It contains a high concentration of phytoestrogens including; flavonoid glycosides (Ginkgo-flavone glycosides, 24\%) and terpene lactones (ginkgolides and bilobalides, $6 \%$ ) [5,6].

Phytoestrogens are near ideal selective estrogen receptor modulators (SERMs) and are considered powerful herbal

Received: August 17, 2018 Accepted: September 21, 2018

Corresponding author: Seung Min Oh

Department of Nanofusion Technology, Hoseo University, 20, Hoseo-ro79beon-

gil, Baebang-eup, Asan-si, ChungcheongNam-do, 31499, Korea

E-mail: ohsm0403@hoseo.edu

*Moon and Kim contributed equally to this study.

This article is available from: http://e-eht.org/ remedies [7]. SERMs have organ-specific estrogenic activity and exhibit antagonistic activity in uterus and breast, and agonistic activity in bone, the cardiovascular system, and brain [8] . Furthermore, plant-derived products containing these compounds might have potential use for hormone replacement therapy (HRT) due to their ER-mediated molecular mechanisms [9]. GBE has been similarly reported to have estrogenic and antiestrogenic activities as determined by in vitro assay $[10,11]$. It has anticancer properties related to its antiangiogenic, antioxidant effects $[12,13]$ and selective estrogen enzyme modulatory effects $[14,15]$. Due to these characteristics, GBE has been considered an HRT for post-menopausal women and breast cancer patients. However, several studies have reported recently HRT might have serious side effects, including endometrial cancer [16]. Therefore, to confirm the side effects on uterus of EGb761, we evaluated its agonistic and antagonistic potentials on uterus using a uterotrophic assay. Uterotrophic assays provide an internationally recognized means of determining the estrogenic and antiestrogenic potential of chemicals $[17,18,19]$ and are based on the development of uterine tissue in the presence of estrogen. In this study, 21-day-old immature female rats were exposed to EGb761 alone or EGb761 plus 17ß-estradiol (E2) or tamoxifen 
(TM). We documented changes in their uterus weights, histologically determined luminal epithelial cell heights (LECH, $\mu \mathrm{m}$ ) and luminal circumferences (LC, $\mu \mathrm{m}$ ), and in estrogenrelated gene expressions in uterus and liver tissues.

\section{METHODS}

\section{Chemicals}

E2 and TM were purchased from Sigma-Aldrich (St. Louis, MO, USA) and dissolved in $100 \%$ ethanol to produce 0.1 and $10 \mathrm{mg} / \mathrm{mL}$ stock solutions, respectively, which were stored at $-20^{\circ} \mathrm{C}$ prior to experiments. The standardized Ginkgo biloba extract (EGb761) was provided by Yuyu pharma Inc. (Seoul, Korea); it contains flavonoids $(25.2 \%)$ and terpene lactones (5.8\%). Prior to treatment, EGb761 diluted with water to concentrations of 10,20 , and $40 \mathrm{mg} / \mathrm{mL}$.

\section{Animals}

Female Crj: CD rats (14 days old) were obtained from DaeHan Bio Link Co., Ltd (Chungbuk, Korea), acclimated for 7 days and provided tap water and a commercial pellet diet (DHL, Co., Ltd, Korea) ad libitum. Animals were maintained in an environmentally controlled room (room temperature, $21 \pm 2^{\circ} \mathrm{C}$; room humidity, $50 \pm 20 \%$ ) under a 12 -h light/dark cycle. During the acclimation and 3 days experiment, general health was monitored twice daily. Animal husbandry was complied with Korean regulations on animal welfare and all procedures were approved beforehand by Review Board in the AB solution Inc. (Suwon, Korea). Every effort was made to minimize animal suffering.

\section{Uterotrophic assay}

Uterotrophic assays were performed according to OECD Test Guideline No. 440 [19]. Briefly, to evaluate the agonist and antagonistic effects of EGb761 on uterus, the rats allocated to 15 groups of six rats (Table 1) by stratified random sampling based on body weight. E2 and TM were dissolved in corn oil at $10 \mu \mathrm{g} / 4 \mathrm{~mL}$ and $1 \mathrm{mg} / 10 \mathrm{~mL}$, respectively, and administered to the rats by subcutaneous (SC) injection (E2: $10 \mu \mathrm{g} / 4 \mathrm{~mL} / \mathrm{kg}$ body weight, TM: 1 mg/4 mL/kg-bw). EGb761 (100, 200 or 400 $\mathrm{mg} / 10 \mathrm{~mL} / \mathrm{kg}$ ) was suspended in water administered by oral gavage. Vehicle controls were administered water (oral gavage, $10 \mathrm{~mL} / \mathrm{kg}$ ) and corn oil (SC injection, $4 \mathrm{~mL} / \mathrm{kg}$ ). All administrations were made once daily for 3 consecutive days. Animals were sacrificed on experimental day 4 by exsanguination from the abdominal aorta. Uteri, including uterine horn, body and cervix, liver, lungs, spleen, and kidneys of the rats were carefully excised and weighed after removing fat and mesentery.

\section{Clinical signs and mortality}

All animals were observed at least twice daily for any clinical signs of toxicity, that is, for behavioral changes (e.g., salivation, fur loss, lethargy, and sleep patterns), for changes in physical appearance (injury, pain, and signs of illness) and for death.

\section{Uterine histology}

Excised uteruses were fixed in $10 \%$ formalin, embedded in paraffin, and stained with hematoxylin and eosin. Epithelial lining cell height and luminal width were measured by using an optical system attached to a light microscope (Olympus cx31, Japan) equipped with a digital CCD camera (IMTscan cooled model, Germany).

Table 1. Experimental design 1 to evaluate estrogenic and antiestrogenic effect of Ginkgo Biloba extract (EGb761) in immature female rat model.

\begin{tabular}{|c|c|c|}
\hline Groups & Chemicals and Dose & $\begin{array}{c}\text { The number of } \\
\text { female rats }\end{array}$ \\
\hline G1 & Control (corn oil/water treatment) & 6 \\
\hline G2 & $17 \beta$-Estradiol (E2, $10 \mu \mathrm{g} / \mathrm{kg})$ & 6 \\
\hline G3 & EGb1 (EGb761 100 mg/kg) & 6 \\
\hline G4 & EGb2 (EGb761 200 mg/kg) & 6 \\
\hline G5 & EGb4 (EGb761 400 mg/kg) & 6 \\
\hline G6 & Control (corn oil/water treatment) & 6 \\
\hline G7 & E2 $(10 \mu \mathrm{g} / \mathrm{kg})$ & 6 \\
\hline G8 & E2 $(10 \mu \mathrm{g} / \mathrm{kg})+\mathrm{EGb} 1(\mathrm{EGb} 761100 \mathrm{mg} / \mathrm{kg})$ & 6 \\
\hline G9 & E2 $(10 \mu \mathrm{g} / \mathrm{kg})+$ EGb2 $(\mathrm{EGb761} 200$ mg/kg) & 6 \\
\hline G10 & E2 $(10 \mu \mathrm{g} / \mathrm{kg})+$ EGb4 $(\mathrm{EGb761} 400 \mathrm{mg} / \mathrm{kg})$ & 6 \\
\hline G11 & Control (corn oil/water treatment) & 6 \\
\hline G12 & Tamoxifen (TM, 1 mg/kg) & 6 \\
\hline G13 & TM (1 mg/kg) + EGb1 (EGb761 100 mg/kg) & 6 \\
\hline G14 & TM (1 mg/kg) + EGb2 (EGb761 200 mg/kg) & 6 \\
\hline G15 & TM (1 mg/kg) + EGb4 (EGb761 400 mg/kg) & 6 \\
\hline
\end{tabular}

Table 2. Primers used for polymerase chain reaction (PCR) analysis

\begin{tabular}{|c|c|c|c|c|c|}
\hline Genes & & Primer (5'-3') & Annealing Temp. $\left({ }^{\circ} \mathrm{C}\right)$ & PCR Cycle & Amplicon(bp) \\
\hline Insulin-like growth factor binding protein (IGFBP-1) & $\begin{array}{l}\mathrm{F} \\
\mathrm{R}\end{array}$ & $\begin{array}{l}\text { CAACAGAAAGCAGGAGATGAGA } \\
\text { GAAGAAGGAGGGAGGAAACAAC }\end{array}$ & 63 & 27 & 234 \\
\hline Calcium binding protein (CaBP9) & $\begin{array}{l}\mathrm{F} \\
\mathrm{R}\end{array}$ & $\begin{array}{l}\text { TGTCTGACTCTGGCAGCACTCACTG } \\
\text { CCTTCAGGAGGCTGGGGAACTCTG }\end{array}$ & 63 & 30 & 181 \\
\hline Cytochrome c Oxidase I (C01) & $\begin{array}{l}\mathrm{F} \\
\mathrm{R}\end{array}$ & $\begin{array}{l}\text { TGAGCAGGAATAGTAGGGACAGC } \\
\text { GAGTAGAAATGATGGAGGAAG }\end{array}$ & 50 & 28 & 261 \\
\hline
\end{tabular}


RNA isolation and reverse transcription polymerase chain reaction (RT-PCR)

Total RNA was extracted from uteruses and livers using Trizol Reagent (Gibco BRL, Grand Island, NY, USA) according to the manufacturer's protocol and stored at $-80^{\circ} \mathrm{C}$ until needed. First-strand complementary DNA (cDNA) was generated by reverse transcribing $1 \mu \mathrm{g}$ of total RNA in a final volume of 20 $\mu \mathrm{L}$ containing $4 \mu \mathrm{L}$ of $5 \times$ RT buffer, $9 \mathrm{U}$ of avian myeloblastosis virus (AMV) reverse transcriptase, $20 \mathrm{U}$ of the RNase inhibitor, $1 \mu \mathrm{L}$ of $10 \mathrm{mM} \mathrm{dNTPs}$, and $0.5 \mu \mathrm{g} / \mathrm{mL}$ of random hexamer. The following conditions were used for RT: room temperature for $10 \mathrm{~min}, 42^{\circ} \mathrm{C}$ for $50 \mathrm{~min}$ and $94^{\circ} \mathrm{C}$ for $5 \mathrm{~min}$.

The primers used for PCR were synthesized by Bioneer (Daejeon, Korea), and are listed in Table 2. PCR was conducted with $2 \mu \mathrm{L}$ of first-strand cDNA in a final volume of $20 \mu \mathrm{L}$, which contained $1 \mu \mathrm{L}$ up- and $1 \mu \mathrm{L}$ down-specific primer and PCR premix (Bioneer, Daejeon, Korea) dissolved in $16 \mu \mathrm{L} 0.1 \%$ diethyl pyrocarbonate (DEPC) distilled water. The following PCR conditions were used: $94^{\circ} \mathrm{C}$ for $2 \mathrm{~min}$ followed by $27-30$ cycles of $94^{\circ} \mathrm{C}$ for 30 s, $50^{\circ} \mathrm{C}$ (Cytochrome c Oxidase I; CO1), $63^{\circ} \mathrm{C}$ (Calcium Binding Protein; CaBP-9), or $53^{\circ} \mathrm{C}$ (Insulin like growth factor binding protein 1; IGFBP-1) for $30 \mathrm{~s}$, and $72{ }^{\circ} \mathrm{C}$ for $1 \mathrm{~min}$, and a final extension step of $72{ }^{\circ} \mathrm{C}$ for $10 \mathrm{~min}$. PCR-amplified products were resolved in $1.5 \%$ agarose gels in $1 \times$ Tris-acetate EDTA (TAE) buffer containing $5 \%$ ethidium bromide (EtBr). PCR product sizes are provided in Table 2, and products were identified using gel documentation and quantified using ImageJ $1.43 \mathrm{u}$ software (NIH, USA). mRNA amounts were normalized with CO1.

Table 3. Body weight, mortality, and clinical signs in immature female rats exposed to Ginkgo Biloba extract (EGb761) or combination of EGb761 and estradiol (E2) or tamoxifen (TM).

\begin{tabular}{|c|c|c|c|c|c|}
\hline Groups & & $\begin{array}{l}\text { Initial Body } \\
\text { weight (g) }\end{array}$ & $\begin{array}{l}\text { Last Body } \\
\text { weight (g) }\end{array}$ & Mortality & $\begin{array}{l}\text { Clinical } \\
\text { signs }^{a}\end{array}$ \\
\hline G1 & Control & $40.74 \pm 3.26$ & $44.86 \pm 2.98$ & $0 / 6$ & $0 / 6$ \\
\hline G2 & E2 & $41.87 \pm 4.76$ & $44.99 \pm 4.63$ & $0 / 6$ & $0 / 6$ \\
\hline G3 & EGb1 & $41.82 \pm 3.02$ & $45.89 \pm 3.02$ & $0 / 6$ & $0 / 6$ \\
\hline G4 & EGb2 & $43.34 \pm 3.92$ & $44.35 \pm 6.00$ & $0 / 6$ & $0 / 6$ \\
\hline G5 & EGb4 & $41.67 \pm 2.33$ & $45.10 \pm 2.59$ & $0 / 6$ & $0 / 6$ \\
\hline G6 & Control & $41.46 \pm 3.25$ & $45.61 \pm 3.44$ & $0 / 6$ & $0 / 6$ \\
\hline G7 & E2 & $41.07 \pm 3.37$ & $44.57 \pm 2.78$ & $0 / 6$ & $0 / 6$ \\
\hline G8 & $\mathrm{E} 2+\mathrm{EGb} 1$ & $41.60 \pm 3.43$ & $45.41 \pm 4.80$ & $0 / 6$ & $0 / 6$ \\
\hline G9 & $\mathrm{E} 2+\mathrm{EGb} 2$ & $39.70 \pm 3.72$ & $43.63 \pm 2.97$ & $0 / 6$ & $0 / 6$ \\
\hline G10 & E2+EGb4 & $41.59 \pm 3.89$ & $45.79 \pm 4.62$ & $0 / 6$ & $0 / 6$ \\
\hline G11 & Control & $34.92 \pm 3.80$ & $39.91 \pm 3.50$ & $0 / 6$ & $0 / 6$ \\
\hline G12 & $\mathrm{TM}$ & $34.96 \pm 3.63$ & $39.06 \pm 3.38$ & $0 / 6$ & $0 / 6$ \\
\hline G13 & $\mathrm{TM}+\mathrm{EGb} 1$ & $33.33 \pm 1.98$ & $37.60 \pm 1.91$ & $0 / 6$ & $0 / 6$ \\
\hline G14 & $\mathrm{TM}+\mathrm{EGb2}$ & $34.16 \pm 3.46$ & $38.48 \pm 3.58$ & $0 / 6$ & $0 / 6$ \\
\hline G15 & $\mathrm{TM}+\mathrm{EGb} 4$ & $34.90 \pm 2.80$ & $39.16 \pm 3.13$ & $0 / 6$ & $0 / 6$ \\
\hline
\end{tabular}

abehavioral pattern (salivation, fur loss, lethargy, and sleep patterns), changes in physical appearance, injury, pain, and signs of illness; Control (corn oil/water treatment); E2: $10 \mu \mathrm{g} / \mathrm{kg}$; EGb1: $100 \mathrm{mg} / \mathrm{kg}$ of EGb761; EGb2: $200 \mathrm{mg} / \mathrm{kg}$ of EGb761; EGb4: $400 \mathrm{mg} / \mathrm{kg}$ of EGb761; TM: $1 \mathrm{mg} / \mathrm{kg}$.

\section{Statistical analysis}

Data were analyzed using Sigma Plot software (Jandel Science Software, San Rafael, CA, USA) and Excel (Microsoft, Redmond, WA, USA). Results are presented as means \pm standard deviation (SD). Statistical analysis was performed using SPSS version 18.0 (SPSS, Chicago, IL, USA). Levene's test was used for confirming homogeneity of variances. Tukey's HSD test followed by oneway analysis of variance (ANOVA) was used to analyze parametric data, and the Mann Whitney test followed by the Kruskal-Wallis test was used to analyze nonparametric data. Statistical significance was accepted for $\mathrm{p}$ values $<0.05$.

\section{RESULTS}

\section{Body weight, clinicall signs, and mortality}

As shown in Table 3, there were no significant changes in initial and last body weight in any treated group as compared

Table 4. Absolute/relative organ weight in immature female rats exposed to Ginkgo Biloba extract (EGb761)

\begin{tabular}{|c|c|c|c|c|c|}
\hline Groups & & Liver & Lung & Spleen & Kidney \\
\hline G1 & CON & $\begin{array}{c}1.39 \pm 0.12 \\
(3.10 \pm 0.17)\end{array}$ & $\begin{array}{c}0.39 \pm 0.03 \\
(0.88 \pm 0.03)\end{array}$ & $\begin{array}{c}0.16 \pm 0.01 \\
(0.36 \pm 0.02)\end{array}$ & $\begin{array}{c}0.44 \pm 0.01 \\
(0.99 \pm 0.07)\end{array}$ \\
\hline G2 & E2 & $\begin{array}{c}1.48 \pm 0.18 \\
(3.28 \pm 0.10)\end{array}$ & $\begin{array}{c}0.41 \pm 0.04 \\
(0.89 \pm 0.06)\end{array}$ & $\begin{array}{c}0.18 \pm 0.02 \\
(0.39 \pm 0.03)\end{array}$ & $\begin{array}{c}0.45 \pm 0.05 \\
(0.99 \pm 0.05)\end{array}$ \\
\hline G3 & FGb1 & $\begin{array}{r}1.61 \pm \\
(3.49 \pm\end{array}$ & $\begin{array}{c}0.40 \pm \\
(0.87 \pm\end{array}$ & $\begin{array}{c}0.20 \pm 0.04 \\
(0.44 \pm 0.06)\end{array}$ & $\begin{array}{c}0.48 \pm 0.07 \\
(1.04 \pm 0.11)\end{array}$ \\
\hline G4 & EGb2 & $\begin{array}{c}1.62 \pm 0.13 \\
\left(3.69 \pm 0.48^{\star}\right)\end{array}$ & $\begin{array}{c}0.42 \pm 0 \\
(0.95 \pm 0\end{array}$ & $\begin{array}{c}0.18 \pm 0.03 \\
(0.42 \pm 0.12)\end{array}$ & $\begin{array}{c}0.46 \pm 0.04 \\
(1.05 \pm 0.13)\end{array}$ \\
\hline G5 & EGb4 & & $\begin{array}{c}0.40 \pm 0 \\
(0.87 \pm 0\end{array}$ & & $\begin{array}{c}0.43 \pm 0.03 \\
(0.96 \pm 0.06)\end{array}$ \\
\hline G6 & $\mathrm{CON}$ & & & & \\
\hline G7 & E2 & & & & \\
\hline G8 & ab1 & $\begin{array}{r}1.64 \pm 0 \\
(3.59 \pm 0\end{array}$ & $\begin{array}{c}0.42 \pm 0.03 \\
(0.94 \pm 0.15)\end{array}$ & $\begin{array}{c}0.17 \pm 0.02 \\
(0.37 \pm 0.02)\end{array}$ & $\begin{array}{c}0.44 \pm 0.05 \\
(0.97 \pm 0.07)\end{array}$ \\
\hline G9 & $\mathrm{E} 2+\mathrm{EGb} 2$ & $\begin{array}{c}1.48 \pm 0.14 \\
(3.40 \pm 0.17)\end{array}$ & $\begin{array}{c}0.38 \pm 0.04 \\
(0.87 \pm 0.06)\end{array}$ & $\begin{array}{c}0.15 \pm 0.03 \\
(0.35 \pm 0.05)\end{array}$ & $\begin{array}{c}0.41 \pm 0.03 \\
(0.95 \pm 0.08)\end{array}$ \\
\hline G1 & 4 & $\begin{array}{c}1.70 \pm 0.23 \\
(3.69 \pm 0.19)\end{array}$ & $\begin{array}{c}0.42 \pm 0.05 \\
(0.92 \pm 0.03)\end{array}$ & $\begin{array}{c}0.16 \pm 0.03 \\
(0.34 \pm 0.05)\end{array}$ & $\begin{array}{c}0.44 \pm 0.05 \\
(0.97 \pm 0.04)\end{array}$ \\
\hline G11 & $\mathrm{CON}$ & $\begin{array}{c}1.30 \pm 0.13 \\
(3.29 \pm 0.54)\end{array}$ & $\begin{array}{c}0.38 \pm( \\
(0.97 \pm C\end{array}$ & $\begin{array}{c}0.18 \pm 0.04 \\
(0.46 \pm 0.12)\end{array}$ & $\begin{array}{c}0.40 \pm 0.03 \\
(1.02 \pm 0.14)\end{array}$ \\
\hline G12 & $\mathrm{TM}$ & $\begin{array}{c}1.20 \pm 0.13 \\
(3.06 \pm 0.11)\end{array}$ & $\begin{array}{c}0.35 \pm 0.02 \\
(0.90 \pm 0.05)\end{array}$ & $\begin{array}{c}0.17 \pm 0.01 \\
(0.43 \pm 0.04)\end{array}$ & $\begin{array}{c}0.40 \pm 0.05 \\
(1.03 \pm 0.06)\end{array}$ \\
\hline G13 & $\mathrm{TM}+\mathrm{EGb} 1$ & $\begin{array}{c}1.22 \pm 0.09 \\
(3.24 \pm 0.18)\end{array}$ & $\begin{array}{c}0.36 \pm 0.03 \\
(0.96 \pm 0.07)\end{array}$ & $\begin{array}{c}0.14 \pm 0.02 \\
(0.38 \pm 0.05)\end{array}$ & $\begin{array}{c}0.36 \pm 0.01 \\
(0.95 \pm 0.03)\end{array}$ \\
\hline G14 & $\mathrm{TM}-$ & $\begin{array}{c}1.31 \pm 0.20 \\
(3.39 \pm 0.23)\end{array}$ & $\begin{array}{c}0.36 \pm 0.02 \\
(0.95 \pm 0.07)\end{array}$ & $\begin{array}{l}0.15 \pm \\
(0.39 \pm\end{array}$ & $\begin{array}{c}0.35 \pm 0.06 \\
(0.93 \pm 0.20)\end{array}$ \\
\hline G15 & TM+EGb4 & $\begin{array}{c}1.39 \pm 0.16 \\
(3.55 \pm 0.33)\end{array}$ & $\begin{array}{c}0.35 \pm 0.03 \\
(0.92 \pm 0.07)\end{array}$ & $\begin{array}{c}0.16 \pm 0.05 \\
(0.40 \pm 0.09)\end{array}$ & $\begin{array}{c}0.40 \pm 0.03 \\
(1.02 \pm 0.03)\end{array}$ \\
\hline
\end{tabular}

21-day-old female Crj:CD (SD) rats were treated with EGb761 once daily for 3 days. Each group consisted of 6 animals. The animals were sacrificed at the age of 24 days. Values in parentheses are relative organ weights (organ weight per body weight, \%). The results are expressed as the mean \pm SD. Values significantly different from the control are indicated by an asterisk ( ${ }^{*} \mathrm{p}<0.05$ ). Control (corn oil/water treatment); 17b-estradiol (E2): $10 \mu \mathrm{g} / \mathrm{kg}$; EGb1: $100 \mathrm{mg} / \mathrm{kg}$ of EGb761; EGb2: 200 $\mathrm{mg} / \mathrm{kg}$ of EGb761; EGb4: $400 \mathrm{mg} / \mathrm{kg}$ of EGb761; Tamoxifen (TM): $1 \mathrm{mg} / \mathrm{kg}$. Organ weight of kidney is value for sum of right and left organ. 
with vehicle controls. During the 4-day experimental period, no clinical sign or mortality was observed in any group of EGb761 exposure (Table 3).

\section{Organ weights}

Livers, lungs, spleens, and kidneys were excised on experimental day 4, trimmed free of fat, and weighed. Weights of lungs, spleens, and kidney were not changed by EGb761 exposure, except for a significant increase in relative liver weight in the $200 \mathrm{mg} / \mathrm{kg}$ EGb761 group (G4) (Table 4).

\section{Uterine weights and histology}

Uteri were pierced, blotted to remove excess fluid, and weighed. As shown in Figure 1, the positive control, E2 (10 $\mu \mathrm{g} /$ $\mathrm{kg}$ ) showed a significant increase in absolute and relative uterine weights $\left({ }^{* *} \mathrm{p}<0.01\right)$, whereas EGb761 did not show a significant increase in uterine weight at any concentration (100,
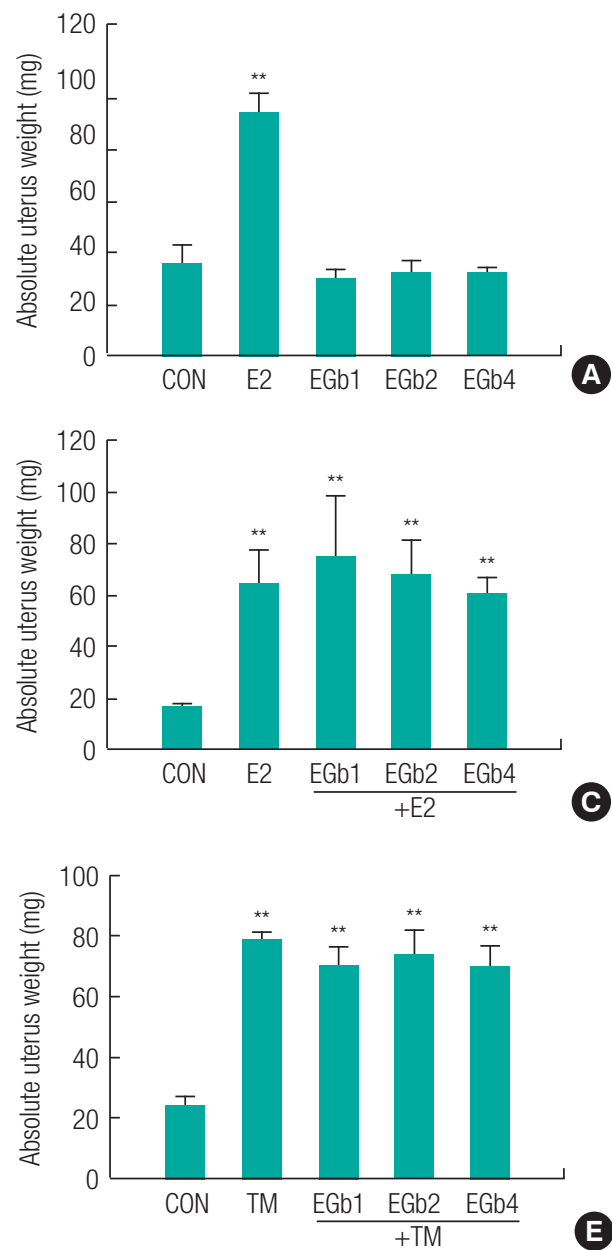

200 or $400 \mathrm{mg} / \mathrm{kg}$ ) (Figures $1 \mathrm{~A}$ and $1 \mathrm{~B}$ ). Absolute and relative weights of uteri increased by E2 $(10 \mu \mathrm{g} / \mathrm{kg})$ or TM $(10 \mathrm{mg} / \mathrm{kg})$ were not significantly decreased by EGb761 at any concentration (Figures 1C, 1D, 1E, and 1F).

For morphometric analysis of cross sections of uterus midhorns, LECH and LC were measured at a magnification of $x$ 400 (Figure 2). Increases in LECH and LC of uterus are histological hallmarks of uterotrophy, which can be induced by estrogen [20]. As shown in Figure 2, both E2 and TM significantly increased (**p < 0.01) LECH and LC normalized with vehicle controls, whereas EGb761 did not even at its highest concentration (400 mg/kg). In addition, EGb761 (400 mg/kg) did not cause a significant reduction in E2- or TM-induced increases in LECH or LC, which indicated EGb761 had no estrogenic and antiestrogenic activity.
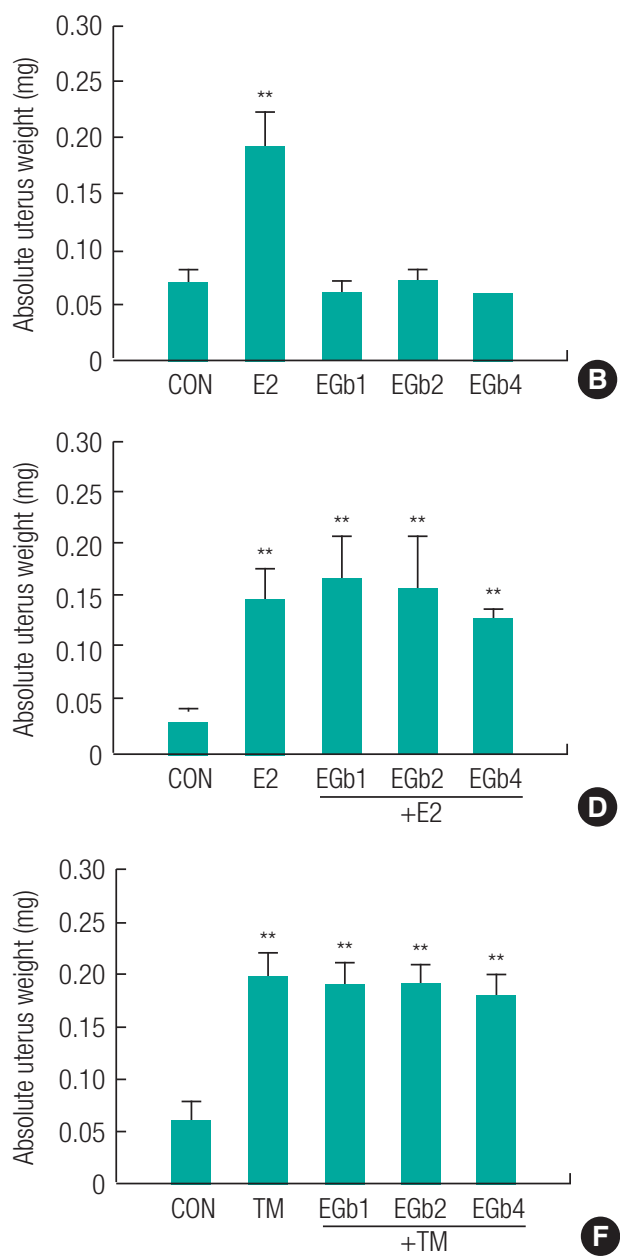

Figure 1. Estrogenic and antiestrogenic effect on uterine weight in immature female rats exposed to Ginkgo biloba extract (EGb761) or combination of EGb761 and 17b-estradiol (E2) or tamoxifen (TM). 21-day-old female Crj:CD (SD) rats ( $n=6)$ were treated with E2 (10 mg/kg) or TM (1 mg/kg) as a positive control, EGb761 (EGb1 = $100 \mathrm{mg} / \mathrm{kg}, E G b 2=200 \mathrm{mg} / \mathrm{kg}, \mathrm{EGb} 4=400 \mathrm{mg} / \mathrm{kg})(\mathrm{A}, \mathrm{B})$, combination of EGb761 (EGb1, EGb2, EGb4) and E2 (C, D) or TM (E, F) once daily for 3 days. The animals were sacrificed at the age of 24 days. The results are expressed as the mean \pm SD. Values are significantly different from the control $\left({ }^{\star *} p<0.01\right)$. 

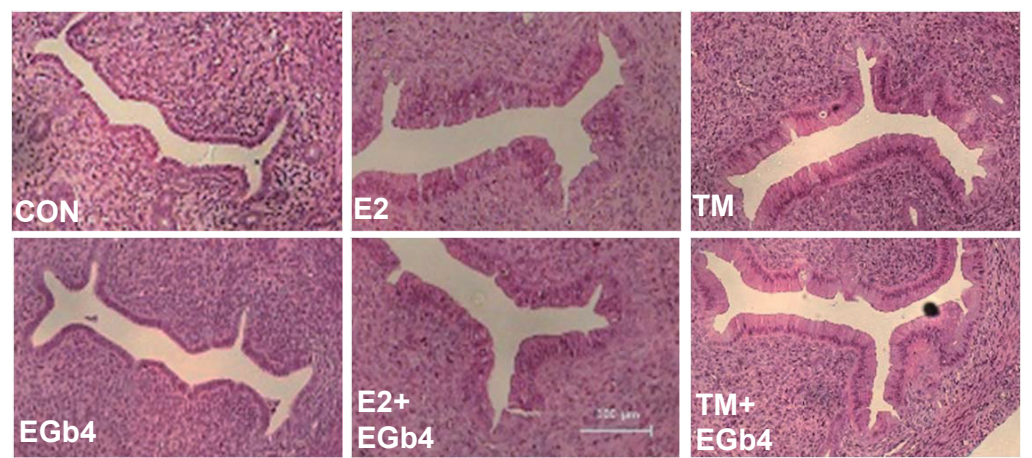

A
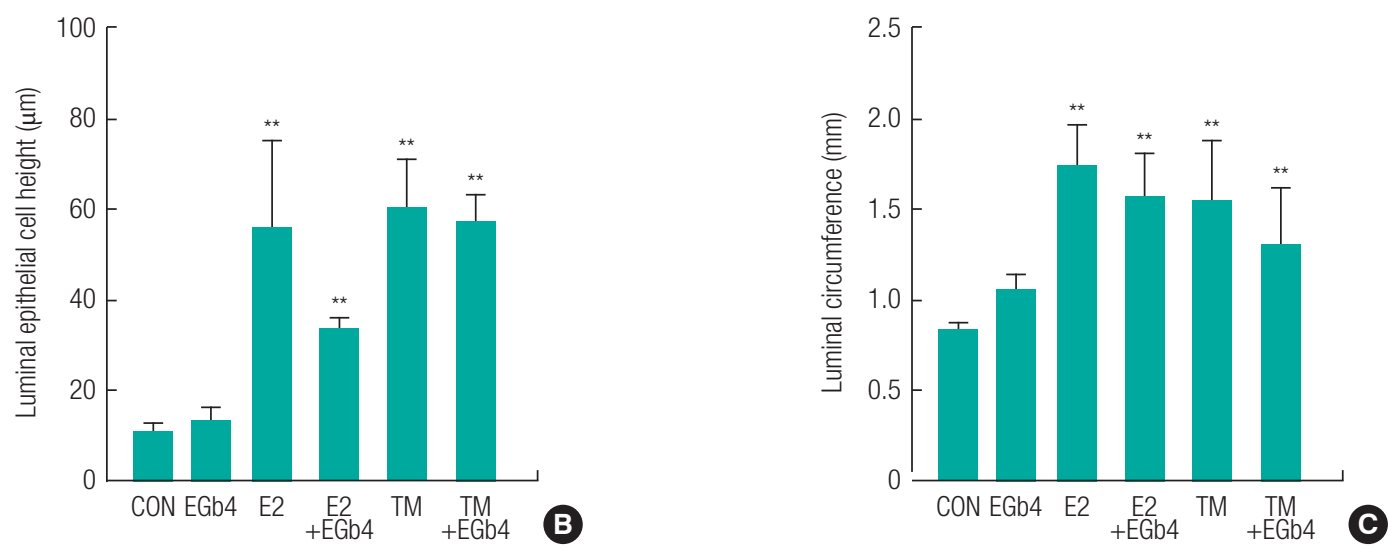

Figure 2. Estrogenic and antiestrogenic activity on uterine in immature female rats exposed to Ginkgo biloba extract (EGb761). 21-day-old female Crj: CD (SD) rats $(n=6)$ were treated with $17 \beta$-estradiol $(E 2,10 \mathrm{mg} / \mathrm{kg})$ or tamoxifen $(\mathrm{TM}, 10 \mathrm{mg} / \mathrm{kg})$ as a positive control and EGb761 (400 mg/kg) once daily for 3 days. Excised uteri from the rats were fixed in $10 \%$ buffered formalin, processed to slide for morphology, and stained with hematoxylin-eosin (A). Luminal epithelium is indicated by arrows (Magnification, $\times 400$ ). Each group consisted of 3 animals. Luminal epithelial lining cell height (LECH) (B) and luminal circumference(LC) $(C)$ is expressed as a relative measurement based on calibrations in an ocular micrometer on the microscope (Magnification, $\times 400)$. The results are expressed as the mean \pm SD of three separate experiments for each group. Values are significantly different from the CON (control group) $\left({ }^{* *} p<0.01\right)$.
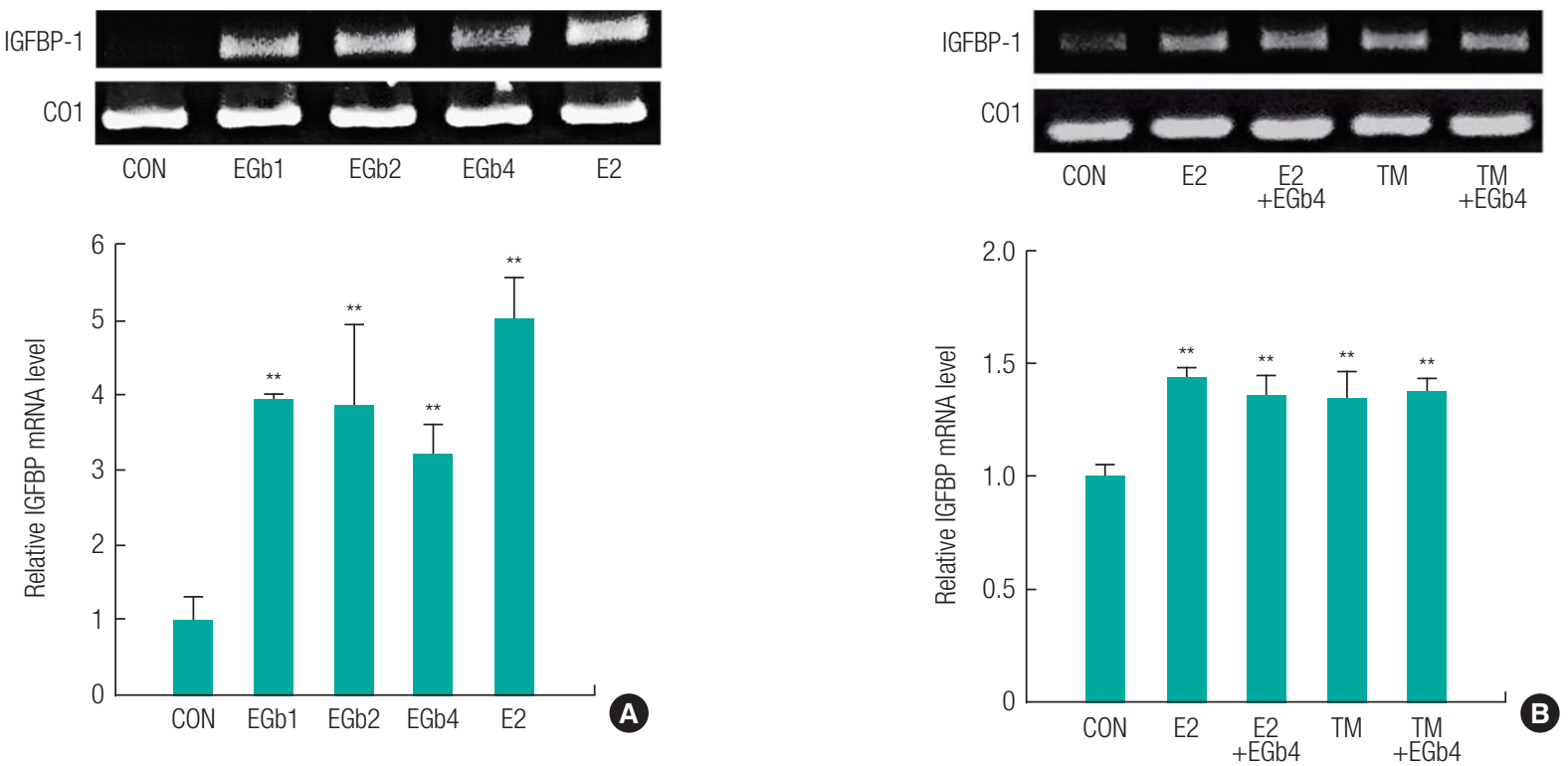

Figure 3. Relative mRNA expression of estrogen-relative genes in liver from immature female rats exposed to Ginkgo biloba extract (EGb761) alone (A) or the combination of EGb761 and 17ß-estradiol (E2) or tamoxifen (TM) (B). The total RNA was extracted using TRIzol in liver obtained from the immature female rats exposed to respective compounds. The mRNA levels (IGFBP) were measured using RT-PCR along with cytochrome c 0xidase I (C01) mRNA as the internal standard. The PCR product was identified using a gel documentation and quantified by Image $1.43 \mathrm{u}$. The results are expressed as mean \pm SD of three separate experiments for each group. Values significantly different from the control are indicated by an asterisk $\left.{ }^{\star *} \mathrm{p}<0.01\right)$. 

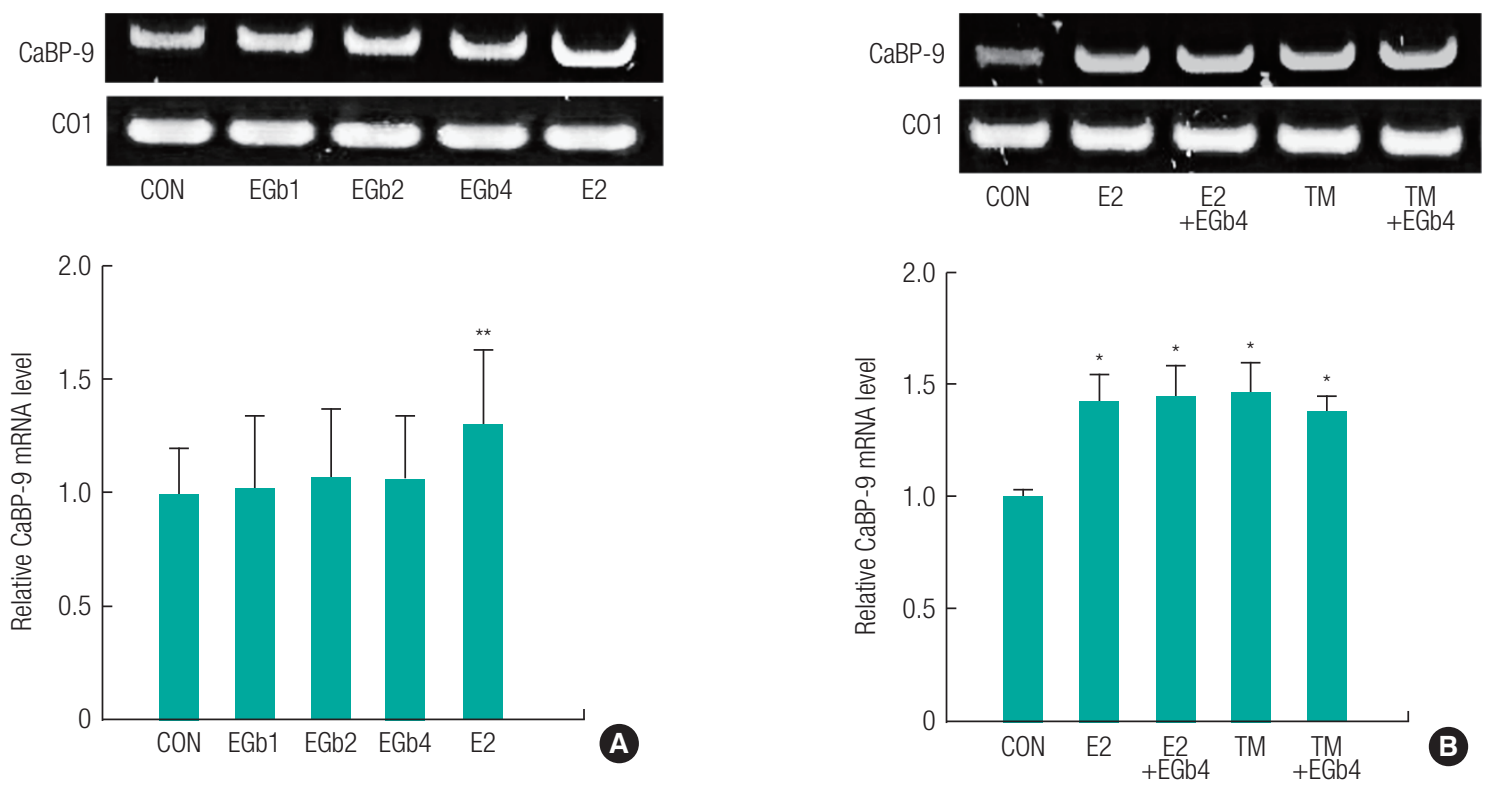

Figure 4. Relative mRNA expression of estrogen-relative genes in uterus from immature female rats exposed to Ginkgo biloba extract (EGb761) alone (A) or the combination of EGb761 and 17 $\beta$-estradiol (E2) or tamoxifen (TM) (B). The total RNA was extracted using TRlzol in liver obtained from the immature female rats exposed to respective compounds. The mRNA levels of CaBP-9 were measured using RT-PCR along with cytochrome $c$ Oxidase I (C01) mRNA as the internal standard. The PCR product was identified using a gel documentation and quantified by Image $1.43 u$. The results are expressed as mean \pm SD of three separate experiments for each group. Values significantly different from the control are indicated by an asterisk $\left({ }^{\star} p<0.05,{ }^{\star \star} p<0.01\right)$.

\section{Estrogen relative gene expressions in liver and uterus}

To further examine the estrogenic and antiestrogenic activities of EGb761, we evaluated the gene expression levels of IGFBP-1 on liver (Figure 3) and CaBP-9 in uterus (Figure 4). In liver tissues, E2 (the positive control) significantly induced a 3.99-fold increase in the expression of IGFBP-1 (estrogen responsive gene). EGb761 significantly increased IGFBP mRNA levels by 3 to 4 -fold all concentrations normalized with vehicle controls. However, IGFBP mRNA upregulations by E2 or TM were not diminished by EGb761 (Figure 3B). In uterine tissues, E2 significantly increased CaBP-9 mRNA levels by 1.31-fold normalized with vehicle controls, whereas EGb761 did not at any concentration (Figure 4A). In addition, E2 or TM-induced CaBP-9 mRNA level increases were unaffected by EGb761 (Figure 4B). These results indicate EGb761 had an agonistic effect in liver, but not in uteri, and no antagonistic effect on either tissue type.

\section{DISCUSSION}

The uterotrophic assay using immature female SD rats recommended by the Endocrine disrupters screening and testing advisor committee (EDSTAC) has been used as in vivo short-term screening assay to evaluate estrogenic and antiestrogenic activities $[18,19,21,22]$. The endpoint of the uterotrophic assay is an increase in uterine weight caused by ER-mediated water imbibition and cellular proliferation in uterine tissues [23]. In this study, E2 (10 $\mu \mathrm{g} / \mathrm{kg}$, i.p. injection, positive control) significantly increased absolute and relative uterus weights, whereas EGb761 $(100,200$, or $400 \mathrm{mg} / \mathrm{kg})$ did not do so as compared with vehicle controls (Figure 1). LECH and LC are hallmarks of the estrogen activity in rodents and are correlated with increases in uterine wet weights $[20,24]$. However, in the present study, uterine LECHs, LC and uterine weights were not significantly increased by EGb761 in the immature female rats (Figure 2). These results indicate that EGb761 had no agonistic effect on uterus.

TM is a SERM and has been used to treat ER-positive breast cancer. Although TM has an antagonistic effect on breast cancer cells, it acts as a full agonist in utero and increase the risk of endometrial cancer development [25]. Therefore, we evaluated effects of EGb761 on the agonistic effects of TM and of E2. When rats were exposed to EGb761 plus E2 or TM, EGb761 had no observed antagonistic effect on absolute or relative uterus weight, LECH, or LC increases by E2 or TM. These results indicate that EGb761 does not act as an agonist or antagonist in utero.

Several plant extracts known to contain flavonoids have been studied with respect to uterotrophic response. Neither onion extract, garlic extract [26], Epimedium koreanum extract [27,28], nor Tropaeolum majus L. extract (3-300 mg/kg) [29] elicited any agonistic or antagonistic effect on uterus as deter- 
mined by uterotrophic assay. Although icariin (10 or $20 \mathrm{mg}$ / $\mathrm{kg}$ ) and icaritin (10 or $20 \mathrm{mg} / \mathrm{kg}$ ), which are major components of $E$. koreanum extract, have agonistic and antagonistic effects on uterus, E. koreanum extract ( $100 \mathrm{mg} / \mathrm{kg}$ ) did not exert any agonistic or antagonistic effect [28]. Quercetin and kaempferol, which are major components of EGb761, have been reported to have agonistic and antagonistic effects on estrogenicity (determined using an in vitro assay) $[10,11]$. In an uterotrophic assay using ovariectomized (OVX) rats, 3.55 or $18.42 \mathrm{mg} / \mathrm{kg}$ quercetin did not induce any estrogenic effect on uteri [30], whereas $100 \mathrm{mg} / \mathrm{kg} /$ day quercetin exerted estrogenic effects [31]. In addition, $10 \mathrm{mg} / \mathrm{kg} /$ day quercetin exhibited antiestrogenic effects. These reports indicate quercetin could exert estrogenic or antiestrogenic effects on uterus depending on the exposure dose. The second major flavonoid in EGb761, kaempferol $(1,000 \mathrm{mg} / \mathrm{kg})$ was found to have no effects on agonistic and antagonistic responses in utero in OVX mice $[23,32]$. Stroheker et al. [33] reported that kaempferol elicits no agonistic $(25-200 \mathrm{mg} / \mathrm{kg})$ or antagonistic $(100 \mathrm{mg} / \mathrm{kg}) \mathrm{re}-$ sponse in immature female rats or in OVX rat models. In the present study, EGb761 was found to contain $25.2 \%$ by weight of flavonoids, which included $64 \%$ quercetin and $32 \%$ kaempferol, that is, 100-400 mg EGb761 contained 16-64 mg and 8-32 mg of quercetin and kaempferol, respectively. However, EGb761 did not exert either of these effects. Oh et al. [34] reported that GBE ( $50-200 \mathrm{mg} / \mathrm{kg}$ ) administered to OVX rats for 6 weeks did not show agonistic effects on uterus. In addition, Opuntia ficus-indica (L.) Mill (250 and $500 \mathrm{mg} / \mathrm{kg}$ ) extract, which contained quercetin, kaempferol, and isorhamnetin, had no agonistic effects on uterus in OVX rat models [9]. On the other hand, onion extract ( $30 \mathrm{mg} / \mathrm{kg}$ ), which contained the same flavonoids as EGb761 (quercetin, kaempferol, and isorhamnetin), was found to have agonistic effects on the uteri of female Wistar immature mice [26]. These reports suggest that complex plant extracts may affect the uterus in ways quite different from single major components.

To evaluate the estrogenic and antiestrogenic potentials of EGb761 in an immature uterotrophic model further, we examined the gene expression of CaBP-9 in uterine tissues using real-time PCR. The estrogen-dependent response of CaBP-9 in rat uterus is regulated by imperfect palindromic estrogen response elements (ERE) $[35,36]$ and CaBP-9 is a known valuable biomarker of potential estrogenic activity [37]. In the present study, EGb761 treatment did not significantly change CaBP-9 mRNA levels in uterine tissues, which also suggests EGb761 had no estrogenic or antiestrogenic potential in utero.

However, unlike that observed in uterine tissues, EGb761 induced IGFBP-1 (a hepatic estrogenic marker) in liver. The up- regulation of IGFBP-1 mRNA in liver is a clear marker of estrogenic regulation in vivo and in vitro [38,39,40]. IGFBP-1 has been reported to play a central role as a hepatic survival factor for liver injury of carbon tetrachloride [41] and as an early detection of alcohol-induced liver damage [42]. Tada et al. [43] reported that long-term feeding of GBE in aged, spontaneously hypertensive rats significantly increased liver weights and serum alanine aminotransferase levels. Hepatoblastomas and non-neoplastic lesions were observed in the livers of rats exposed to GBE for 2 years [44]. However, several other studies have reported GBE has hepatic protective effects for obstructive jaundice [45], hepatocarcinogenesis [46], and liver fibrosis [47]. In addition, Lieberman et al. [48] reported that ginkgo intake (EGb761) as typically consumed by American adults showed no significant adverse effects on liver function. Based on the controversial results of the GBE, further studies were needed to clarify the effects of GBE on liver function.

\section{CONCLUSION}

Ginkgo biloba has been used as a traditional Chinese medicine for treating cerebrovascular and peripheral vascular insufficiencies. GBE (a SERM) has been studied in the contexts of HRT and its anticarcinogenic effects in breast tissues. However, HRT might have serious side effects, including endometrial cancer. In a uterotrophic assay, EGb761 (100, 200, or 400 $\mathrm{mg} / \mathrm{kg}$ ) did not show any change of uterine weight, estrogenrelated gene expression (CaBP-9), and histopathological effects (LECH and LC) on the uterus. These results suggested that EGb761 has no agonistic and antagonistic effects on uterus.

\section{ACKNOWLEDGEMENTS}

This work was supported by a grant from the National Research Foundation of Korea funded by the Korean Government (NRF-2013R1A1A2A10060109).

\section{CONFLICT OF INTEREST}

The authors have no conflict of interest associated with the material presented in this paper.

\section{ORCID}

Byeonghak Moon https://orcid.org/0000-0002-2018-6418

Wonchan Kim https://orcid.org/0000-0002-2665-7591

ChoHee Park https://orcid.org/0000-0002-8599-6155

Seung Min Oh https://orcid.org/0000-0002-5701-8960 


\section{REFERENCES}

1. Dubey AK, Shankar PR, Upadhyaya D, Deshpande VY. Ginkgo bilobaan appraisal. Kathmandu Univ Med J (KUMJ) 2004;2(3):225-229.

2. DeFeudis FV, Papadopoulos V, Drieu K. Ginkgo biloba extracts and cancer: a research area in its infancy. Fundam Clin Pharmacol 2003;17(4):405-417.

3. Ude C, Schubert-Zsilavecz M, Wurglics M. Ginkgo biloba extracts: a review of the pharmacokinetics of the active ingredients. Clin Pharmacokinet 2013;52(9):727-749.

4. ADIS R\&D PROFILE. EGb 761: ginkgo biloba extract, Ginkor. Drugs R D 2003;4(3):188-193.

5. Drieu K. Preparation and Definition of Ginkgo Biloba Extract. In: Funfgeld EW, editor. Rökan, Ginkgo Biloba: Recent results in pharmacology and clinic. Springer-Verlag 1988; p. 32-36.

6. Stewart AG. Ginkgo biloba extract (EGb761): Pharmacological activities and clinical applications. Trends Pharmacol Sci 1991;13, p 334335.

7. Adlercreutz H, Mazur W. Phyto-oestrogens and western diseases. Ann Med 1997;29(2):95-120.

8. Ibrahim NK, Hortobagyi GN. The evolving role of specific estrogen receptor modulators (SERMs). Surg Oncol 1999;8(2):103-123.

9. An BH, Jeong H, Zhou W, Liu X, Kim S, Jang CY, et al. Evaluation of the biological activity of Opuntia ficus indica as a tissue- and estrogen receptor subtype-selective modulator. Phytother Res 2016;30(6):971980.

10. Oh SM, Chung KH. Estrogenic activities of Ginkgo biloba extracts. Life Sci 2004;74(11):1325-1335.

11. Oh SM, Chung KH. Antiestrogenic activities of Ginkgo biloba extracts. J Steroid Biochem Mol Biol 2006;100(4-5):167-176.

12. Pincemail J, Thirion A, Dupuis M, Braquet P, Drieu K, Deby C. Ginkgo biloba extract inhibits oxygen species production generated by phorbol myristate acetate stimulated human leukocytes. Experientia 1987;43(2):181-184.

13. Monte M, Davel LE, de Lustig ES. Inhibition of lymphocyte-induced angiogenesis by free radical scavengers. Free Radic Biol Med, 1994; 17(3):259-266.

14. Kim MJ, Park YJ, Chung KH, Oh SM. The inhibitory effects of the standardized extracts of ginkgo biloba on aromatase activity in JEG-3 human choriocarcinoma cells. Phytother Res 2013;27(12): 1756-1762.

15. Park YJ, Ahn HY, Kim HY, Chung KH, Oh SM. Ginkgo biloba extract EGb 761-mediated inhibition of aromatase for the treatment of hormone-dependent breast cancer. Food Chem Toxicol, 2016;87:157165.

16. Chuffa LG, Lupi-Júnior LA, Costa AB, Amorim JP, Seiva FR. The role of sex hormones and steroid receptors on female reproductive cancers. Steroids 2017;188:93-108.

17. Laws SC, Carey SA, Ferrell JM, Bodman GJ, Cooper RL. Estrogenic activity of octylphenol, nonylphenol, bisphenol A and methoxychlor in rats. Toxicol Sci 2000;54(1):154-167.

18. Shelby MD, Newbold RR, Tully DB, Chae K, Davis VL. Assessing environmental chemicals for estrogenicity using a combination of in vitro and in vivo assays. Environ Health Perspect 1996; 104(12):1296-1300.

19. Organiztion for Economic Co-operation and Development. Uterotrophic bioassay in rodents: a short-term screening test for oestrogenic properties cited 2012 Oct 7. Available from: www.epa.gov/endo/ pubs/uterotrophic_OECD_guideline.pdf.

20. Owens JW, Ashby J. Critical review and evaluation of the uterotrophic bioassay for the identification of possible estrogen agonists and antagonists: in support of the validation of the OECD uterotrophic protocols for the laboratory rodent. Organisation for Economic Co-operation and Development. Crit Rev Toxicol 2002;32(6): 445-520.

21. Baker VA. Endocrine disrupters-testing strategies to assess human hazard. Toxicol In Vitro 2001; 15(4-5):413-419.

22. Clode SA. Assessment of in vivo assays for endocrine disruption. Best Pract Res Clin Endocrinol Metab 2006;20(1):35-43.

23. Kleinstreuer NC, Ceger PC, Allen DG, Strickland J, Chang X, Hamm JT, et al. A curated database of rodent uterotrophic bioactivity. Environ Health Perspect 2016;124(5):556-562.

24. Loeb L, Suntzeff V, Burns EL. Growth processes induced by estrogenic hormones in the uterus of the mouse. Am J Cancer 1938;34(3):413-427.

25. Tomas E, Kauppila A, Blanco G, Apaja-Sarkkinen M, Laatikainen T. Comparison between the effects of tamoxifen and toremifene on the uterus in postmenopausal breast cancer patients. Gynecol Oncol 1995;59(2):261-266.

26. Alrefaie ZA, Mostafa HA, El-Gayed SH, Al-Hayani AA. Estrogenicity of outer scales of onion on reproductive functions of mice. Intern J Appl Res Vet Med 2010;8(3):170-179.

27. Zhang DW, Cheng Y, Wang NL, Zhang JC, Yang MS, Yao XS. Effects of total flavonoids and flavonol glycosides from Epimedium koreanum Nakai on the proliferation and differentiation of primary osteoblasts. Phytomedicine 2008;15(1-2):55-61.

28. Kang HK, Choi YH, Kwon H, Lee SB, Kim DH, Sung CK, et al. Estrogenic/antiestrogenic activities of a Epimedium Koreanum extract and its major components: in vitro and in vivo studies. Food Chem Toxicol 2012;50(8):2751-2759.

29. Lourenco EL, Muller JC, Boareto AC, Gomes C, Lourenco A, Minatovicz B, et al. Screening for in vivo (anti)estrogenic and (anti)androgenic activities of Tropaeolum majus L. and its effect on uterine contractility. J Ethnopharmacol 2012;141(1):418-423.

30. Rachoń D, Vortherms T, Seidlová-Wuttke D, Jarry H, Wuttke W. Dietary Quercetin does not affect pituitary luteinizing hormone (LH) expression and has no uterotrophic effects in ovariectomized SpraueDawley rats. Food Chem Toxicol 2008;46(2):513-518.

31. Shahzad H, Giribabu N, Sekaran M, Salleh N. Quercetin induces dose-dependent differential morphological and proliferative changes in rat uteri in the presence and in the absence of estrogen. J Med Food 2015;18(12):1307-1316.

32. Ohta R, Takagi A, Ohmukai H, Marumo H, Ono A, Matsushima Y, et al. Ovariectomized mouse uterotrophic assay of 36 chemicals. J Toxicol Sci 2012;37(5):879-889.

33. Stroheker T, Chagnon MC, Pinnert MF, Berges R, Canivenc-Lavier MC. Estrogenic effects of food wrap packaging xenoestrogens and flavonoids in female Wistar rats: a comparative study. Reprod Toxicol 2003;17(4):421-432.

34. Oh SM, Kim HR, Chung KH. Effects of Ginkgo biloba on in vitro osteoblast cells and ovariectomized rat osteoclast cells. Arch Pharm Res 2008;31(2):216-224.

35. Krisinger J, Setoyama T, Leung PC. Expression of calbindin-D9K in the early pregnant rat uterus: effect of RU486 and correlation to estro- 
gen receptor mRNA. Mol Cell Endocrinol 1994;102(1-2):15-22.

36. Darwish H, Krisinger J, Furlow JD, Smith C, Murdoch FE, DeLuca HF. An estrogen-responsive element mediates the transcriptional regulation of calbindin D-9k gene in rat uterus. J Biol Chem 1991;266(1): 551-558.

37. Jung EM, An BS, Yang H, Choi KC, Jeung EB. Biomarker genes for detecting estrogenic activity of endocrine disruptors via estrogen receptors. Int J Environ Res Public Health 2012;9(3):698-711.

38. Molnar P, Murphy LJ. Effects of oestrogen on rat uterine expression of insulin-like growth factor-binding proteins. J Mol Endocrinol, 1994; 13(1):59-67.

39. Diel P, Walter A, Fritzemeier KH, Hegele-Hartung C, Knauthe R. Identification of estrogen regulated genes in Fe33 rat hepatoma cells by differential display polymerase chain reaction and their hormonal regulation in rat liver and uterus. J Steroid Biochem Mol Biol, 1995; 55(3-4):363-373.

40. Suh DS, Ooi GT, Rechler MM. Identification of cis-elements mediating the stimulation of rat insulin-like growth factor-binding protein-1 promoter activity by dexamethasone, cyclic adnosin 3,5'-monophosphate, and phorbol esters, and inhibition by insulin. Mol Endocrinol 1994;8(6):794-805.

41. Scharf JG, Dombrowski F, Novosyadlyy R, Eisenbach C, Demori I, Kübler B, et al. Insulin-like growth factor (IGF)-binding protein-1 is highly induced during acute carbon tetrachloride liver injury and potentiates the IDF-1-stimulated activation of rat hepatic stellate cells. Endocrinology 2004;145(7):3463-3472.

42. Li HH, Doiron K, Patterson AD, Gonzalez FJ, Fornace J Jr. Identifica- tion of serum insulin-like growth factor binding protein 1 as diagnostic biomarker for early-stage alcohol-induced liver disease. J Transl Med 2013;11:266.

43. Tada Y, Kagota S, Kubota Y, Nejime N, Nakamura K, Kunitomo M, et al. Long-term feeding of ginkgo biloba extract impairs peripheral circulation and hepatic function in aged spontaneously hypertensive rats. Biol Pharm Bull 2008;31(1):68-72.

44. Rider CV, Nyska A, Cora MC, Kissling GE, Smith C, Travlos GS, et al. Toxicity and carcinogenicity studies of ginkgo biloba extract in rat and mouse: liver, thyroid, and nose are targets. Toxicol Pathol 2013; 42(5):830-843.

45. Weng MZ, Zhou XP, Jia JG, Ding J, Fang CF, Qin YY, et al. The hepatic protective mechanism of ginkgo biloba extract in rats with obstructive jaundice. Bosn J Basic Jed Sci 2011;11(4):209-213.

46. El Mesallamy HO, Metwally NS, Soliman MS, Ahmed KA, Abdel Moaty MM. The chemopreventive effect of ginkgo biloba and silybum marianum extracts on hepatocarcinogenesis in rats. Cancer Cell Int 2011;11(1):38.

47. Al-Attar AM. Attenuating effect of ginkgo biloba leaves extract on liver fibrosis induced by thioacetamide in mice. J Biomed Biotechnol 2012; Article ID 761450, 9 pages.

48. Lieberman HR, Kellogg MD, Fulgoni VL 3rd, Agarwal S. Moderate doses of commercial preparations of Ginkgo biloba do not alter markers of liver function but moderate alcohol intake does: A new approach to identify and quantify biomarkers of 'adverse effects' of dietary supplements. Regul Toxicol Pharmacol 2017;84:45-53. 